\title{
PENGARUH LEVEL PUPUK BOKASHI KOTORAN AYAM TERHADAP PERTUMBUHAN LAMTORO (Leucaena leucocephala)
}

\author{
Marsela Tendean, D. A. Kaligis*, D. Rustandi, W. B. Kaunang \\ Fakultas Peternakan, Universitas Sam Ratulangi
}

\begin{abstract}
ABSTRAK
Penelitian ini bertujuan mempelajari pengaruh level pupuk organik bokashi kotoran ayam terhadap pertumbuhan Lamtoro. Perlakuan yang diuji level Bokashi terdiri dari $\mathrm{B} 1=0$ gram, $B 2=200$ gram, $B 3=400$ gram dan $B 4=800$ gram/polybag. Perlakuan diulang sebanyak 7 kali dan analisis keragaman berdasarkan pola percobaan Rancangan Acak Lengkap (RAL). Peubah yang diukur adalah tinggi tanaman, jumlah daun majemuk dan jumlah anak daun. Hasil analisis statistik menunjukkan pemberian bokashi kotoran ayam sebanyak 400 dan 800 gram/polybag memberikan pengaruh yang sangat nyata $(\mathrm{P}<0,01)$ terhadap tinggi tanaman, jumlah daun, dan panjang daun. Uji lanjut Tuckey Simultaneous Test menunjukkan level pupuk organik bokashi sebanyak 400 dan 800 gram/polybag memberikan hasil untuk semua peubah yang diukur nyata $(\mathrm{P}<0,05)$ lebih baik dibandingkan level bokashi lainnya. Berdasarkan hasil penelitian dapat disimpulkan bahwa penggunaan pupuk bokashi asal kotoran ayam sebanyak 400 gram/polybag cukup baik untuk mendapatkan performans Leucaena leucocephala (Lamtoro) yang terukur pada peubah tinggi tanaman, jumlah daun majemuk dan jumlah anak daun.
\end{abstract}

Kata kunci: Bokashi, leucaena, pertumbuhan, kotoran ayam.

\footnotetext{
*Korespondensi (corresponding Author)
}

Email: kaligis.david@unsrat.ac.id

\begin{abstract}
THE EFFECT OF CHICKEN MANURE BOKASHI LEVEL ON GROWTH OF LAMTORO (Leucaena leucocephala). The aim of this experiment was to study the effect of organic fertilizer Bokashi from chicken manure on performance of Leucaena leucocephala in term of tall of plant, number of compound leaves and number of leaflets. Treatment consisted of four level of bokashi as follows $\mathrm{B} 1=0$ gram, B2 $=200$ gram, B3 $=400$ gram and $\mathrm{B} 4=800$ gram bokashi/ polybag. Design has been used was Completely Randomized Design (CRD) with 7 replications. Analysis of variance showed that level of bokashi at 400 and 800 gram / polybag gave a significant difference $(\mathrm{P}<0,05)$ better than others levels in term of tall of plant, number of compound leaves and number of leaflets. Tuckey Simultaneous Test showed that both treatments gave the significant different $(\mathrm{P}<0,05)$ higher than others levels. Based on these results it can be concluded that application of 400 gram/polybag organic fertilizer bokashi chicken manure enough to produce good performance of Lamtoro (Leucaena leucocephala) in term of tall of plant, number of compound leaves and number of leaflets.
\end{abstract}

Keywords: Bokashi, leucaena, growth, chicken manure. 


\section{PENDAHULUAN}

Penelitian ini dilaksanakan di

Di Indonesia telah banyak dilakukan studi tentang agronomi dari $L$. leucocephala. Pada tahun 1988, telah mulai dilakukan seleksi species Leucaena tahan kutu loncat dan pada tahun 1993 diperoleh 41 asesi hibrida dari 8 species Leucaena yang berasal dari koleksi plasma nutfah yang lepaskan oleh Nitrogen Fixing Tress Association Hawai.

Sebagaimana tanaman lain, laucaena membutuhkan suplay unsur hara yang cukup, yang dapat diperoleh dari pupuk pabrik. Namun demikian jenis pupuk organik ini selain berharga relatif lebih mahal juga berdampak negatif terhadap lingkungan tanah dan air.

Pupuk organik merupakan pupuk yang berasal dari sampah organik termasuk kotoran ternak diantaranya kotoran ayam petelur. Bahan organik ini harus melalui proses dekomposisi oleh kegiatanmikro organism seperti yang terdapat dalam effective microorganisme (EM4) sebelum digunakan sebagai pupuk. Penelitian ini bertujuan mempelajari pengaruh penggunaan pupuk organik bokashi asal kotoran ayam terhadap pertumbuhan tanaman legume pohon Leucaena leucocephala (Lamtoro).

\section{MATERI DAN METODE PENELITIAN}

Laboratorium Agrostologi Fakultas Peternakan UNSRAT Manado dimulai sejak 23 Februari sampai 23 Mei 2017. Bahan yang digunakan adalah : Biji Lamtoro (Leucaena leucocephala), kotoran ayam, EM4, gula putih + molases, air sumur, kulit kopi, dedak halus dan tanah sebagai media tanam. Alat yang digunakan adalah sebagai berikut : Cangkul, meter, timbangan, parang, kamera, bambu, paku, kertas HVS warna, tali, plastik, gunting.

\section{Metode penelitian}

Penelitian ini menggunakan Rancangan Acak Lengkap (RAL) menurut Steel dan Torrie ( 1995). Perlakuan pupuk bokashi terdiri dari B1=0 gram; B2= 200 gram, B3= 400 gram dan $B 4=800$ gram/polybag. Perlakuan diulang sebanyak 7 kali, dengan demikian diperoleh 28 angka pengamatan.

\section{Variabel Yang Diukur :}

1. Tinggi tanaman $(\mathrm{cm})$, diukur mulai dari permukaan tanah hingga bagian ujung daun, dilakukan sejak minggu pertama sampai minggu ke lima setelah dipindahkan dalam polybag.

2. Jumlah daun majemuk (helai), diukur meliputi keseluruhan daun majemuk yang berada di setiap batang tanaman dalam polybag, dilakukan sejak minggu pertama sampai minggu ke lima setelah dipindahkan dalam polybag. 
3. Jumlah anak daun (helai): dihitung semua helai anak daun pada setiap daun majemuk pada semua tanaman dalam polybag, dilakukan sejak minggu pertama sampai minggu ke lima setelah dipindahkan dalam polybag, Jumlah helai anak daun di kalikan dengan jumlah daun majemuk.

\section{Prosedur Penelitian}

1. Pembuatan bokashi (Kusuma, 2012).

Tahap pertama pembuatan pupuk bokashi kotoran ayam

a. Persiapan bahan :

Larutan EM4 ( $1 / 2$ liter $)+$ molasses $(1 / 2$ liter $)+$ air dicampur merata.

b. Siapkan bahan- bahan pengisi :

Kotoran ayam $(100 \mathrm{~kg})+$ dedak halus $(10 \mathrm{~kg})+$ sekam padi $(20 \mathrm{~kg})$, dan kulit kopi (60 kg ), + air secukupnya.

c. Proses pembuatan:

Semua bahan pengisi dicampur bertahap mulai dari kulit kopi, sekam padi, dedak halus, diberikan larutan EM4 yang telah dicampur dengan air. Semua bahan dicampur homogen, lalu ditutup menggunakan karung goni dan terpal. Untuk pengecekan suhu dilakukan setiap 5-6 jam dengan suhu dipertahankan $40-50^{\circ} \mathrm{C}$. Apabila terjadi peningkatan suhu pada bahan olahan, dilakukan pembongkaran dengan cara membolak - balikan bahan tersebut, agar terjadi penurunan suhu. Kemudian ditutup selama 2-4 minggu. Pupuk sudah dapat digunakan apabila memiliki ciri berwarna hitam, gembur, tidak panas, dan tidak berbau.

\section{Penyediaan tanah}

Tanah yang digunakan dihancurkan homogen, dikeringkan tanpa sinar matahari selama 1 minggu. Selanjutnya tanah kering tersebut seberat $4 \mathrm{Kg}$ dimasukan kedalam polybag berdiameter $30 \mathrm{~cm}$ setelah terlebih dahulu dicampur dengan pupuk bokashi sesuai perlakuan level pupuk yang diuji.

\section{Penyiapan benih lamtoro.}

Sebelum disemai biji lamtoro diskarifikasi dengan menggunakan kertas pasir berukuran (1) untuk mempercepat proses germinasi. Setelah kecambah berumur 10 hari setelah tumbuh (HST) dalam pesemaian, selanjutnya dipilih dua tanaman yang vigor sebagai tanaman sampel.

\section{Penanaman dan pemeliharaan tanaman. \\ Dipilih dua kecambah yang vigor} kemudian dipindahkan ke dalam polybag yang telah diisi dengan tanah kering sebanyak $4 \mathrm{Kg}$ dan telah dicampur merata dengan pupuk organik bokashi sesuai perlakuan yang diuji. 
Tanaman ditempatkan di rumah kaca dan disiram sebanyak $240 \mathrm{ml}$ per polybag tiap pagi dan petang dan dilakukan kontrol gulma.

\section{HASIL DAN PEMBAHASAN}

Pengaruh perlakuan level bokashi kotoran ayam terhadap tinggi tanaman, jumlah daun majemuk dan jumlah anak daun disajikan pada Tabel 1.

\section{Tinggi Tanaman}

Hasil analisis keragaman menunjukkan pengaruh perlakuan level pupuk organik bokashi kotoran ayam berbeda sangat nyata $(\mathrm{P}<0.05)$ terhadap tinggi tanaman. Hasil uji lanjut dengan Tuckey Simultaneous Test menunjukan perlakuan level bokashi 400 dan 800 gram berbeda nyata $(\mathrm{P}<0,05)$ ukuran tanaman lebih tinggi dibandingkan level bokashi 0 dan 200 gram per polybag. Semakin tinggi level pupuk bokashi semakin tinggi pula tanaman lamtoro, diduga karena pupuk bokashi asal kotoran ayam mengandung unsur hara yang lengkap dan $\mathrm{C} / \mathrm{N}$ rasio yang ideal (Hartatik dan Widowati, 2006).

\section{Jumlah Daun Majemuk}

Sebagaimana performans tinggi tanaman pengaruh perlakuan terhadap jumlah daun majemuk menurut hasil uji lanjut menunjukkan perlakuan level bokashi 400 dan 800 gram berbeda nyata $(\mathrm{P}<0,05)$ terhadap jumlah daun majemuk dibanding dengan level pupuk 0 gram dan 200 gram/polybag. Unsur N sangat dibutuhkan dalam pembentukan klorofif, dimana kandungan unsur nitrogen $(\mathrm{N})$ pada bokashi kotoran ayam $1.30 \%$ lebih tinggi dibandingkan dengan $\mathrm{N}$ dalam bokashi

Tabel 1. Rataan Pengaruh Perlakuan Level Bokashi Kotoran Ayam Terhadap Tinggi Tanaman, Jumlah Daun, Jumlah Daun Majemuk Lamtoro.

\begin{tabular}{cccc}
\hline Perlakuan & $\begin{array}{c}\text { Tinggi tanaman } \\
(\mathrm{cm})\end{array}$ & $\begin{array}{c}\text { Jumlah daun } \\
\text { majemuk (helai) }\end{array}$ & $\begin{array}{c}\text { Jumlah anak } \\
\text { daun (helai) }\end{array}$ \\
\hline B1 & $31,15^{\mathrm{c}}$ & $29,29^{\mathrm{c}}$ & $728,57^{\mathrm{c}}$ \\
B2 & $52,98^{\mathrm{b}}$ & $49,43^{\mathrm{b}}$ & $1237,50^{\mathrm{b}}$ \\
B3 & $68,49^{\mathrm{a}}$ & $63,50^{\mathrm{a}}$ & $1587,50^{\mathrm{a}}$ \\
B4 & $72,31^{\mathrm{a}}$ & $71,31^{\mathrm{a}}$ & $1796,40^{\mathrm{a}}$ \\
\hline
\end{tabular}

Keterangan:

Superscript yang berbeda pada kolom yang sama menunjukkan perbedaan yang nyata $(\mathrm{P}<0,05)$. 
kotoran kambing $1.12 \%$ dan dalam bokashi kotoran sapi hanya $0.95 \%$ (Hartatik dan Widowati, 2006). Dengan demikian peningkatan tersebut mungkin terkait juga dengan serapan $\mathrm{P}$ dan $\mathrm{N}$ yang banyak terkandung dalam bokashi kotoran ayam ini. Selain unsur makro $P$ ternyata unsur kalium (K) dalam bokashi kotoran ayam sebanyak $1.39 \%$ lebih tinggi dibandingkan dengan bokashi kotoran kambing dan sapi, masing-masing berturut-turut 1.07 dan $0.58 \%$ (Hartatik dan Widowati, 2006). Unsur kalium berpengaruh dalam proses pertumbuhan tubuh tanamam yang menyebabkan tanaman bertumbuh tegak dan kuat (Sucipto, 2010). Unsur P merupakan unsur hara yang esensial bagi tanaman, yang berperan dalam proses pertumbuhan tanaman, meliputi proses fotosintesis, respirasi, transfer dan penyimpanan energi, pembelahan dan pembesaran sel serta proses-proses yang lainya (Sudaryono, 2009). Kandungan unsure hara makro yang relatif tinggi tersebut bersinergi dengan titik tumbuh dan percabangan yang bertambah jumlahnya memungkinkan efisiensi fotosintesis pada tanaman legume pohon (Anis et al., 2016). Unsur hara $\mathrm{N}$ merupakan bahan penting penyusun asam amino, amida, nukleotida dan nukleoprotein, serta esensial untuk pembelahan sel, pembesaran sel dan karenanya untuk pertumbuhan (Gardner et al., 1991; Ferguson et al., 2010) dibutuhkan tanaman dalam jumlah banyak di dalam bagian muda tanaman,terutama terakumulasi pada daun dan biji, yang berfungsi sebagai penyusun protein, termasuk enzim dan molekul khlorofil (Hakim et al., 1986).

\section{Jumlah Anak Daun (helai)}

Pengaruh perlakuan terhadap hasil anak daun sejalan dengan daun majemuk dimana perlakuan level pupuk bokashi 400 dan 800 gram/polybag menghasilkan jumlah anak daun terbanyak dan berbeda nyata $(\mathrm{P}<0,05)$ dibanding dengan perkauan level pupuk bokashi 0 dan 200 gram.

Hasil uji lanjut dengan Tuckey Simultaneous Test menunjukkan B3 dan B4 berbeda tidak nyata $(\mathrm{P}>0.05)$ akan tetapi perlakuan B3 dan B4 menunjukkan berbeda nyata dengan B2 dan B1 terhadap jumlah anak daun $(P<0,05)$. Sebagaimana kebutuhan nitrogen oleh daun majemuk demikian juga kebutuhan $\mathrm{N}$ oleh komponen anak daun. Pertumbuhan jumlah daun berkaitan dengan peran $\mathrm{N}$ sebagai komponen klorofil, bertambahnya $\mathrm{N}$ dalam tanah berasosiasi dengan pembentukan dan pertambahan jumlah daun tanaman (Kusuma, 2003).

Kandungan unsur hara $\mathrm{K}$ sekitar $40 \%$ berpengaruh dalam proses pembentukan daun, dimana tanaman sangat membutuhkan unsur hara kalium dalam pembentukan karbohidrat sehingga 
menghasilkan jumlah daun yang banyak (Sucipto, 2010).

\section{KESIMPULAN}

Berdasarkan hasil peneltian ini dapat ditarik kesimpulan penggunaan pupuk bokashi kotoran ayam sebanayk 800 gram/polybag memberikan hasil yang terbaik pada tinggi tanaman, jumlah daun majemuk, dan jumlah anak daun lamtoro (Leucaena leucocephala).

\section{DATAR PUSTAKA}

Anis, S. D., D. A. Kaligis, B. Tulung, and Aryanto. 2016. Leaf quality and yield of Gliricidia sepium (Jacq) steud under different population density and cutting interval in coconut plantation. J. Indonesia Trop. Anim. Agric 41 (2) : 91-98.

Ferguson, B. J., A. Indra Sumunar, S. Hayashi, Meng-Han Lin, YuHsiang Lin, D.E. Reid, dan P. M. Gressoff_2010. Molecular analysis of legume nodule development and autoregulation. Journal Of Integrative Plant Biology. 52 (1): 61 -76.

Gardner, F.P., R.B. Pearce, and R.L. Mitchell. 1991. Fisiologi Tanaman Budidaya. Diterjemahkan oleh: Susilo, H. dan Subiyanto. Penerbit Universitas Indonesia, Jakarta.
Hakim, N., M.Y. Nyakpa, A.M. Lubis, S.G. Nugroho, M.R. Saul, M.A. Diha, G.B. Hong, dan H.H. Bailey. 1986. Dasar-dasar Ilmu Tanah. Universitas Lampung. hlm. 488.

Hartatik, W., L.R Widowati. 2006. Pupuk Kandang. hal 59 - 82. Dalam R.D.M. Simanugkalit, D. A. Suriadikarta, R. Saraswati, D. Setyorini, W. Hartatik (Eds). Pupuk Organik dan Pupuk Hayati. Balai Besar Litbang Sumber daya Lahan Pertanian, Badan Penelitian dan Pegembangan Pertanian, Bogor.

Kusuma, M. E. 2012. Pengaruh Beberapa Jenis Pupuk Kandang Terhadap Kualitas Bokashi . Jurnal Ilmu Hewan Tropika. Vol 1 (2): 41-46

Kusuma, M. E, 2013. Pengaruh pemberian bokhasi terhadap pertumbuhan vegetatif dan produksi rumput gajah (Pennicetum purpureum). Jurnal Ilmu Hewan Tropika Vol 2 (2): 40-45.

Sucipto. 2010. Efisiensi cara pemupukan terhadap pertumbuhan dan hasil beberapa varietas sorgum manis ( Sorgum bicolor L.Moench). Jurnal Embryo 7 (2) : 67-74.

Sudaryono. 2009. Tingkat kesuburan tanah ultisol pada lahan pertambagan batubara Sangatta, Kalimantan Timur. J. Tek Ling. 10(3):337-346 